\title{
Diabetes and Obesity-Cumulative or Complementary Effects On Adipokines, Inflammation, and Insulin Resistance
}

\author{
Adela-Viviana Sitar-Taut ${ }^{1, *} \mathbb{0}$, Sorina Cezara Coste ${ }^{1}$, Simina Tarmure ${ }^{1}$, Olga Hilda Orasan ${ }^{1}(\mathbb{D}$, \\ Adriana Fodor ${ }^{2}{ }^{\circledR}$, Vasile Negrean ${ }^{1}$, Dana Pop ${ }^{3}$, Dumitru Zdrenghea ${ }^{3}$, Cezar Login ${ }^{4}$, \\ Brandusa Tiperciuc ${ }^{5}$ (D) and Angela Cozma ${ }^{1}$ \\ 1 Internal Medicine Department, 4th Medical Clinic "Iuliu Haţieganu” University of Medicine and Pharmacy, \\ 400012 Cluj-Napoca, CJ, Romania; secara.sorina@yahoo.com (S.C.C.); siminatarmure@yahoo.com (S.T.); \\ olgaorasan@yahoo.com (O.H.O.); vasile.negrean@umfcluj.ro (V.N.); angelacozma@yahoo.com (A.C.) \\ 2 Clinical Center of Diabetes, Nutrition, Metabolic diseases, "Iuliu Haţieganu" University of Medicine \\ and Pharmacy, 400012 Cluj-Napoca, CJ, Romania; adifodor@yahoo.com \\ 3 Department of Cardiology, Clinical Rehabilitation Hospital, "Iuliu Haţieganu” University of Medicine \\ and Pharmacy, 400012 Cluj-Napoca, CJ, Romania; pop67dana@gmail.com (D.P.); \\ dzdrenghea@yahoo.com (D.Z.) \\ 4 Department Physiology, "Iuliu Haţieganu” University of Medicine and Pharmacy, \\ 400012 Cluj-Napoca, CJ, Romania; cezar.login@umfcluj.ro \\ 5 Department Pharmaceut Chem "Iuliu Haţieganu” University of Medicine and Pharmacy, \\ 400012 Cluj-Napoca, CJ, Romania; brandu32@yahoo.com \\ * Correspondence: adelasitar@yahoo.com
}

Received: 8 July 2020; Accepted: 22 August 2020; Published: 26 August 2020

\begin{abstract}
Background: Diabetes and obesity are increasingly significant public health issues. The aim of this study was to evaluate the relationship between adipocytokines (leptin, ghrelin, and chemerin), inflammation (sVCAM1—soluble vascular adhesion molecule 1, sICAM1—soluble intercellular adhesion molecule 1), and insulin resistance in the presence of obesity and diabetes mellitus. Methods: 88 subjects, with a mean age of $61.96 \pm 10.15$ years, $75 \%$ of whom were women, were evaluated (in order to consider different associations between obesity and diabetes, subjects were categorized into four groups). Results: Overall, we found significant correlations between sICAM1-sVCAM1 rho $=0.426$ and ghrelin-chemerin rho $=-0.224$. In the obesity + diabetes group, leptin correlated with sICAM1 rho $=0.786$, and sVCAM1 negatively with glycemia/insulin rho $=-0.85$. Significant differences were found between the groups regarding sVCAM1 $(p=0.0134)$, leptin $(p=0.0265)$ and all insulin resistance scores, with differences influenced by the subjects' gender. In conclusion, although there are currently many unknown aspects of the release and the role of various adipokines, in particular chemerin, its implication in early glucose metabolism dysregulation disorders seems very likely.
\end{abstract}

Keywords: diabetes; obesity; adipokines; inflammation; insulin resistance score

\section{Introduction}

Diabetes and obesity currently represent public health issues [1-3], pandemic diseases [4], with a growing incidence [5-8], hundreds of millions of people being diagnosed with obesity or diabetes worldwide. More than $60 \%$ of the United States population are overweight or obese [9], and 463 million adults are diabetic across the world (according to 2019 IDF-International Diabetes Federation reports) [10]. A proportion of $85 \%$ of type 2 diabetic (T2DM) adults are also obese. The risk of diabetes is about nine times higher in obese subjects [11]. 
Early diagnosis and estimation of the risk of complications represent current objectives in order to reduce mortality and morbidity.

At this moment, obesity is described as a heterogeneous syndrome (determined by the genetic and environmental factors' interaction) [8,12-14]. Previous studies have pointed out the different obesity types [15]: "metabolically healthy obesity"-MHO (defined by obesity presence without metabolic disturbance or metabolic syndrome features $[8,12,16]$ and "metabolically unhealthy obesity-MUO" $[8,12,16]$.

MHO patients, despite the fat mass excess, present a more favorable metabolic profile and lower, but still present, risk for late complications [16-18]. At the same time, the MHO concept is still controversial because of many discrepancies in relationship to its definition, prevalence (range between $2-50 \%$ in the previously reported data [16]), and etiopathogenesis, but, especially due to its tendency to eventually evolve into MUO $[8,16]$.

Adipose tissue is a metabolically active [5,6], highly dynamic endocrine and immune organ [9,19-23] that secretes adipocytokines [24], which are involved in the regulation of lipid and carbohydrate metabolism, in the pathogenesis of insulin resistance and diabetes mellitus $[4,5,14,23]$, in immunity, having at the same time a neuroendocrine function. Obesity is accompanied by an alteration of the adipokine profile (changes in the serum levels of adiponectin, leptin, resistin, chemerin, omentin, apelin, adipsin, vaspin, visfatin), as well as by the presence of inflammation (evidenced by changes in the adhesion molecules sICAM1—soluble Intercellular Adhesion Molecule 1 and sVCAM1—soluble Vascular Adhesion Molecule 1) [5,14].

Despite the large amount of data reported to date, there are still many unknown aspects related to the mode of action and the role of various molecules secreted by the adipose tissue, the interaction between them and their implication in the pathogenesis and the diagnosis of insulin resistance and endothelial dysfunction, obesity and diabetes mellitus [25]. The previously mentioned concepts (MHO, MUO) create more difficulties in understanding adiposity-related inflammation and neuroendocrine function, variant molecules' expression being influenced by obesity phenotype.

The aim of this study was to evaluate the relationship between various adipocytokines, markers of inflammation, and insulin resistance (quantified by insulin resistance scores), as well as to monitor the way in which this relationship can be influenced by different combinations in the presence of obesity and diabetes mellitus.

\section{Experimental Section}

The current study was conducted in the Department of Cardiology of the Rehabilitation Hospital in Cluj-Napoca. Eighty-eight subjects with a mean age of $61.96 \pm 10.15$ years, including 66 (75\%) women, were evaluated. All subjects underwent complete clinical examination, and the following was recorded: weight, height, body mass index (weight $(\mathrm{kg}) /\left(\right.$ height ${ }^{*}$ height $\left.\left[\mathrm{m}^{2}\right]\right)$ ), abdominal circumference (measured halfway between the last rib and the iliac crest), systolic and diastolic blood pressure (assessed after $15 \mathrm{~min}$ of rest, according to the recommendations of current guidelines). Cardiovascular risk factors (lipid fractions, obesity, smoking, diabetes, and hypertension) were assessed. The presence of diabetes mellitus was quantified based on the current criteria of the European Society of Cardiology [26]. Subjects were considered obese if body mass index (BMI) $\geq 30 \mathrm{~kg} / \mathrm{m}^{2}$, hypertensive if they had blood pressure values $\geq 140 / 90 \mathrm{mmHg}$ or if they were on hypotensive treatment, and dyslipidaemic if the serum total cholesterol $\geq 200 \mathrm{mg} / \mathrm{dL}$ or serum triglycerides $\geq 150 \mathrm{mg} / \mathrm{dL}$ (according to the 2019 European Society of Cardiology guidelines) [27]. Insulin resistance scores were calculated as follows: * homeostatic model assessment $(\mathrm{HOMA}$ index $)=$ insulin $(\mu \mathrm{U} / \mathrm{mL}){ }^{*}$ glycemia $(\mathrm{mg} / \mathrm{dL}) / 405$; * quantitative insulin sensitivity check index (QUICKI index $=1 /[\lg 10$ (insulin $(\mu \mathrm{U} / \mathrm{mL}))+\lg 10$ (glycemia)); and * McAuley Score for measuring the Insulin Sensitivity Index $=\exp (3.29-0.25$ * $\ln ($ Insulin $)-0.22 * \ln (\mathrm{BMI})-0.28 * \ln$ (triglycerides)).

For each subject, the profile of serum adipokines (leptin, ghrelin, chemerin) was evaluated using the ELISA (enzyme-linked immunosorbent assay) method. The values of the adhesion molecules (soluble Intercellular Adhesion Molecule 1—sICAM1 and soluble Vascular Cell Adhesion Molecule 
1—sVCAM1—in ng/mL) were measured using commercially available ELISA kits (R\&D Systems Inc., Minneapolis, MN, USA).

Subjects with systemic or inflammatory diseases were excluded. The study protocol was approved by the local Ethics Committee (following the Declaration of Helsinki), and all subjects gave their written informed consent.

Statistical analysis of the data was performed using the statistical packages Medcalc version 10.3.0.0 (MedCalc Software, Ostend, Belgium) and SPSS for Windows (v16.0, IBM Corporation, Armonk, NY, USA). For quantitative variables, the normality of the distribution was evaluated using the Kolmogorov-Smirnov and D'Agostino-Pearson tests. The results were presented as the mean \pm standard deviation, median values, respectively, for the quantitative variables (depending on the type of distribution), and as numbers and percentages for qualitative data. To assess the differences between variables, the independent sample $t$-test, Mann-Whitney test or $\chi^{2}$-test were used. The differences between groups were assessed using the ANOVA (analysis of variance) or Kruskal-Wallis test. Spearman and Pearson correlation coefficients were calculated. Optimum sensitivity, specificity, cut-off values, and area under receiver-operating characteristic (ROC) curves were assessed. A $p$-value $<0.05$ was considered statistically significant.

\section{Results}

Eighty-eight subjects with a mean age of $61.96 \pm 10.15$ years, including 66 (75\%) women, were evaluated. The mean age was $65.72 \pm 10.04$ years for men vs. $60.71 \pm 9.94$ years for women $(p=0.04)$. Of all subjects, $27.3 \%$ were diabetic (type $2-\mathrm{T} 2 \mathrm{DM}$ ) and $35.3 \%$ were obese. The characteristics of the studied group are shown in Table 1.

Table 1. Subjects' characteristics.

\begin{tabular}{|c|c|c|c|c|c|}
\hline & & Global & Women & Men & $p$ \\
\hline Number & & 88 & 66 & 22 & \\
\hline Age (years) & & $61.96 \pm 10.15$ & $60.71 \pm 9.94$ & $65.72 \pm 10.04$ & 0.04 \\
\hline $\begin{array}{c}\text { Body mass } \\
\text { index }\left(\mathrm{kg} / \mathrm{m}^{2}\right)\end{array}$ & & $28.85 \pm 4.22$ & $28.88 \pm 4.39$ & $28.73 \pm 3.76$ & NS \\
\hline Obesity & Yes & $31(35.3)$ & $24(36.36)$ & $7(31.81)$ & \multirow{2}{*}{ NS } \\
\hline No $(\%)$ & No & $57(64.7)$ & $42(63.63)$ & $15(68.18)$ & \\
\hline $\begin{array}{c}\text { Abdominal } \\
\text { circumference }(\mathrm{cm})\end{array}$ & & $98.04 \pm 10.41$ & $96.27 \pm 10.40$ & $103.27 \pm 8.70$ & 0.003 \\
\hline $\begin{array}{c}\text { Systolic blood } \\
\text { pressure (mmHg) }\end{array}$ & & $\begin{array}{c}131.59 \pm 16.28 \\
(130)\end{array}$ & $\begin{array}{c}131.43 \pm 16.47 \\
(130)\end{array}$ & $\begin{array}{c}132.04 \pm 16.08 \\
(130)\end{array}$ & NS \\
\hline $\begin{array}{c}\text { Diastolic blood } \\
\text { pressure }(\mathrm{mmHg})\end{array}$ & & $\begin{array}{c}82.78 \pm 15.38 \\
(80)\end{array}$ & $\begin{array}{c}83.56 \pm 16.88 \\
(80)\end{array}$ & $\begin{array}{c}80.45 \pm 9.5 \\
(80)\end{array}$ & NS \\
\hline \multirow{2}{*}{$\begin{array}{l}\text { Hypertension } \\
\text { No }(\%)\end{array}$} & Yes & 70 (79.5) & $53(80.30)$ & $17(77.27)$ & \multirow[b]{2}{*}{ NS } \\
\hline & No & $18(20.5)$ & $13(19.7)$ & $5(22.73)$ & \\
\hline \multirow{2}{*}{$\begin{array}{l}\text { Current smokers } \\
\text { No(\%) }\end{array}$} & Yes & $15(17)$ & $10(15.15)$ & $5(22.72)$ & \multirow{2}{*}{ NS } \\
\hline & No & $73(83)$ & $56(84.85)$ & $17(77.28)$ & \\
\hline \multirow[t]{2}{*}{ Diabetes No (\%) } & Yes & $24(27.3)$ & $16(24.24)$ & $8(36.36)$ & \multirow{2}{*}{ NS } \\
\hline & No & $64(72.7)$ & $50(75.75)$ & $14(63.63)$ & \\
\hline Glycemia (mg/dL) & & $100.35 \pm 34.77$ & $101.34 \pm 38.87$ & $97.36 \pm 17.83$ & NS \\
\hline \multirow{2}{*}{ Dyslipidemia } & Yes & $59(67)$ & $48(72.72)$ & $11(50)$ & \multirow{2}{*}{0.08} \\
\hline & No & $29(33)$ & $18(27.27)$ & $11(50)$ & \\
\hline $\begin{array}{l}\text { Total cholesterol } \\
(\mathrm{mg} / \mathrm{dL})\end{array}$ & & $213.07 \pm 52.82$ & $222.03 \pm 48.09$ & $186.22 \pm 58.24$ & 0.014 \\
\hline $\begin{array}{l}\text { LDL cholesterol } \\
(\mathrm{mg} / \mathrm{dL})\end{array}$ & & $137.05 \pm 41.34$ & $142.87 \pm 37.60$ & $119.59 \pm 47.72$ & 0.045 \\
\hline $\begin{array}{l}\text { Triglycerides } \\
\text { (mg/dL) }\end{array}$ & & $154.50 \pm 69.15$ & $158.65 \pm 73.22$ & $142.04 \pm 54.81$ & NS \\
\hline $\begin{array}{l}\text { HDL cholesterol } \\
(\mathrm{mg} / \mathrm{dL})\end{array}$ & & $42.82 \pm 9.21$ & $44.34 \pm 8.80$ & $38.27 \pm 9.10$ & 0.006 \\
\hline
\end{tabular}


Table 1. Cont.

\begin{tabular}{|c|c|c|c|c|}
\hline & Global & Women & Men & $p$ \\
\hline sICAM1 (ng/mL) * & $\begin{array}{l}120.36 \pm 51.11 \\
\quad(106.00)\end{array}$ & $\begin{array}{c}123.58 \pm 46.74 \\
(108.00)\end{array}$ & $\begin{array}{l}111.77 \pm 61.97 \\
\quad(95.00)\end{array}$ & 0.034 \\
\hline sVCAM1 (ng/mL) * & $\begin{array}{c}1106.48 \pm 452.89 \\
(998.00)\end{array}$ & $\begin{array}{c}1114.33 \pm 460.16 \\
(998.00)\end{array}$ & $\begin{array}{c}1085.55 \pm 445.17 \\
(988.00)\end{array}$ & NS \\
\hline Leptin $(\mathrm{pg} / \mathrm{mL})$ * & $\begin{array}{c}26,201.16 \pm 23,946.59 \\
(20,195.00)\end{array}$ & $\begin{array}{c}32,758.40 \pm 24,533.35 \\
(24,155.00)\end{array}$ & $\begin{array}{c}8168.75 \pm 7559.82 \\
(5150.00)\end{array}$ & $<0.0001$ \\
\hline Ghrelin $(\mathrm{pg} / \mathrm{mL}) *$ & $\begin{array}{l}39.16 \pm 17.34 \\
(34.50)\end{array}$ & $\begin{array}{c}40.37 \pm 19 \\
(35)\end{array}$ & $\begin{array}{l}35.70 \pm 10.97 \\
\quad(33.75)\end{array}$ & NS \\
\hline Chemerin $(\mathrm{pg} / \mathrm{mL})$ * & $\begin{array}{c}8.60 \pm 7.22 \\
(6.30)\end{array}$ & $\begin{array}{c}8.97 \pm 7.72 \\
\quad(6.3)\end{array}$ & $\begin{array}{l}7.47 \pm 5.44 \\
\quad(5.95)\end{array}$ & NS \\
\hline Insulin $(\mu \mathrm{U} / \mathrm{mL})$ & $\begin{array}{c}8.50 \pm 5.19 \\
(7.40)\end{array}$ & $\begin{array}{c}8.88 \pm 5.96 \\
(7.4) \\
\end{array}$ & $\begin{array}{c}7.38 \pm 0.5 \\
(7.25)\end{array}$ & 0.049 \\
\hline HOMA index * & $\begin{array}{c}2.23 \pm 2.29 \\
\quad(1.67)\end{array}$ & $\begin{array}{c}2.38 \pm 2.62 \\
\quad(1.66)\end{array}$ & $\begin{array}{c}1.78 \pm 0.39 \\
(1.78)\end{array}$ & NS \\
\hline QUICKI index * & $\begin{array}{l}0.34 \pm 0.01 \\
\quad(0.35)\end{array}$ & $\begin{array}{l}0.34 \pm 0.02 \\
\quad(0.35)\end{array}$ & $\begin{array}{c}0.35 \pm 0.01 \\
(0.34)\end{array}$ & NS \\
\hline McAuley Score & $1.93 \pm 0.28$ & $1.90 \pm 0.29$ & $2.00 \pm 0.24$ & NS \\
\hline Glycemia/insulin * & $\begin{array}{c}12.55 \pm 3.62 \\
(12.16)\end{array}$ & $\begin{array}{c}12.35 \pm 3.99 \\
(11.83)\end{array}$ & $\begin{array}{c}13.17 \pm 2.13 \\
(12.32)\end{array}$ & 0.05 \\
\hline
\end{tabular}

LDL cholesterol = low-density lipoprotein; HDL cholesterol = high-density lipoprotein cholesterol; sICAM1 = soluble Intercellular Adhesion Molecule 1; sVCAM1 = soluble Vascular Adhesion Molecule 1; HOMA index = homeostatic model assessment; Quicki index = quantitative insulin sensitivity check index; ${ }^{*}$ does not respect the normality distribution; data are presented as the mean \pm standard deviation (median value); for categorical data: number (percentage), $p$ was calculated with Student's test, Mann-Whitney test, or $\chi 2$ test; NS (not statistically significant) $p>0.05$.

Subjects were categorized in groups: group 1, obese + diabetic-13 subjects (14.8\%); group 2, obese only-18 subjects ( $20.5 \%)$; group 3, diabetic only-11 subjects ( $12.5 \%)$; and group 4 , non-diabetic non-obese -46 subjects $(52.3 \%)$. The distribution of subjects in the four groups depending on gender is presented in Table 2, with no significant differences depending on subjects' gender ( $p=$ NS).

Table 2. Distribution of subjects depending on the presence of diabetes and obesity.

\begin{tabular}{ccccc}
\hline & Group 1 & Group 2 & Group 3 & Group 4 \\
\hline & O + D + & O + D - & O - D + & O -D - \\
\hline Number of subjects & 13 & 18 & 11 & 46 \\
Women & $10(76.9)$ & $14(77.77)$ & $6(54.54)$ & $36(78.6)$ \\
Men & $3(23.07)$ & $4(22.22)$ & $5(45.450$ & $10(21.7)$ \\
\hline
\end{tabular}

Differences between groups (regarding adipokine levels, adhesion molecule levels, and insulin resistance scores) were assessed-data are presented in Table 3. Significant differences were found between groups regarding sVCAM1 $(p=0.0134)$, leptin $(p=0.0265)$, and all insulin resistance scores. The differences were influenced by subjects' gender. 
Table 3. Differences between the groups regarding the different parameters (adipokines, adhesion molecules, insulin resistance scores).

\begin{tabular}{|c|c|c|c|c|c|c|c|}
\hline GROUPS & $\begin{array}{c}\text { Group 1 } \\
\text { O + D + } \\
13 \text { Subjects }\end{array}$ & $\begin{array}{c}\text { Group } 2 \\
\text { O + D - } \\
18 \text { Subjects }\end{array}$ & $\begin{array}{c}\text { Group } 3 \\
\text { O - D + } \\
11 \text { Subjects }\end{array}$ & $\begin{array}{c}\text { Group } 4 \\
\text { O - D - } \\
\text { 46 Subjects }\end{array}$ & $\begin{array}{c}\text { Global } p \text { Trend } \\
\text { (Sig Diff between Groups) }\end{array}$ & $\begin{array}{c}p \text { Trend Women } \\
\text { (Sig Diff between Groups) }\end{array}$ & $\begin{array}{c}p \text { Trend Men } \\
\text { (Sig Diff Groups) }\end{array}$ \\
\hline Age & $62.23 \pm 10.05$ & $53.83 \pm 7.95$ & $69.18 \pm 10.6$ & $63.34 \pm 9.06$ & $\begin{array}{c}<0.001 \\
\text { G1 vs. G2, G2 vs. G3, G2 vs. } \\
\text { G4 }\end{array}$ & $\begin{array}{l}<0.001 \\
\text { G1 vs. G2, G2 vs. G3, G2 vs. } \\
\text { G4, G3 vs. G4 }\end{array}$ & NS \\
\hline $\operatorname{sICAM} 1(\mathrm{ng} / \mathrm{mL})^{*}$ & $\begin{array}{l}104.22 \pm 38.70 \\
(94)\end{array}$ & $\begin{array}{c}123.77 \pm 59.99 \\
\quad(112)\end{array}$ & $\begin{array}{c}167.42 \pm 85.54 \\
(142)\end{array}$ & $\begin{array}{c}115.12 \pm 40.63 \\
(106)\end{array}$ & NS & NS & NS \\
\hline sVCAM1 (ng/mL)* & $\begin{array}{l}790.88 \pm 164.87 \\
(742)\end{array}$ & $\begin{array}{l}995.55 \pm 297 \\
(928)\end{array}$ & $\begin{array}{l}1562.57 \pm 858 \\
\quad(1140)\end{array}$ & $\begin{array}{l}1122.24 \pm 371 \\
\quad(1054)\end{array}$ & $\begin{array}{c}0.0134 \\
\text { G1 vs. G3, G1 vs. G4 }\end{array}$ & $\begin{array}{c}0.0385 \\
\text { G1 vs. G3, G1 vs. G4 }\end{array}$ & NS \\
\hline Leptin $(\mathrm{pg} / \mathrm{mL})^{*}$ & $\begin{array}{l}38,121.25 \pm 24,875 \\
\quad(32,810)\end{array}$ & $\begin{array}{l}40,318.88 \pm 28,541 \\
\quad(36,650)\end{array}$ & $\begin{array}{c}33,893.33 \pm 39,946 \\
(14,505)\end{array}$ & $\begin{array}{c}18,942.43 \pm 16,474 \\
(15,950)\end{array}$ & $\begin{array}{l}0.0265 \\
\text { G1 vs. G4, G2 vs. G4 }\end{array}$ & $\begin{array}{c}0.0048 \\
\text { G1 vs. G4, G2 vs. G4 } \\
\text { G3 vs. G4 }\end{array}$ & $\begin{array}{c}0.0175 \\
\text { G1 vs. G4, G2 vs. G3, G2 } \\
\text { vs. G4 }\end{array}$ \\
\hline Ghrelin $(\mathrm{pg} / \mathrm{mL})^{*}$ & $\begin{array}{c}38.30 \pm 18.38 \\
(29.5)\end{array}$ & $\begin{array}{c}43.61 \pm 15.90 \\
(39)\end{array}$ & $\begin{array}{c}34.80 \pm 14.93 \\
(31.7)\end{array}$ & $\begin{array}{c}38.70 \pm 18.22 \\
(34.5)\end{array}$ & NS & NS & NS \\
\hline Chemerin * $(\mathrm{pg} / \mathrm{mL})$ & $\begin{array}{c}7.98 \pm 7.22 \\
(5.2)\end{array}$ & $\begin{array}{c}8.42 \pm 7.55 \\
\quad(5.8)\end{array}$ & $\begin{array}{c}7.27 \pm 5.24 \\
\quad(5.6)\end{array}$ & $\begin{array}{c}9.15 \pm 7.64 \\
\quad(7.15)\end{array}$ & NS & NS & $\begin{array}{l}0.0259 \\
\text { G1 vs. G3, G1 vs. G4, G2 } \\
\text { vs. G4 }\end{array}$ \\
\hline Insulin & $\begin{array}{l}12.51 \pm 12.65 \\
\quad(7.6)\end{array}$ & $\begin{array}{l}8.07 \pm 2.19 \\
\quad(7.4)\end{array}$ & $\begin{array}{l}8.17 \pm 1.66 \\
\quad(7.4)\end{array}$ & $\begin{array}{l}7.60 \pm 0.92 \\
(7.3)\end{array}$ & $\begin{array}{l}0.023 \\
\text { G1 vs. G2, G1 vs. G3, } \\
\text { G1 vs. G4 }\end{array}$ & $\begin{array}{c}0.023 \\
\text { G1 vs. G2, G1 vs. G4 }\end{array}$ & NS \\
\hline HOMA index * & $\begin{array}{l}4.24 \pm 5.12 \\
\quad(2.48)\end{array}$ & $\begin{array}{l}1.90 \pm 0.78 \\
(1.59)\end{array}$ & $\begin{array}{l}2.69 \pm 2.26 \\
\quad(1.87)\end{array}$ & $\begin{array}{l}1.66 \pm 0.28 \\
(1.64)\end{array}$ & $\begin{array}{c}0.0002 \\
\text { G1 vs. G2, G1 vs. G4, G3 vs. } \\
\text { G4 }\end{array}$ & $\begin{array}{l}0.0002 \\
\text { G1 vs. G2, G1 vs. G4, G2 vs. } \\
\text { G3, G3 vs. G4 }\end{array}$ & NS \\
\hline QUICKI index * & $\begin{array}{l}0.32 \pm 0.02 \\
\quad(0.33)\end{array}$ & $\begin{array}{l}0.35 \pm 0.01 \\
\quad(0.35)\end{array}$ & $\begin{array}{l}0.33 \pm 0.02 \\
\quad(0.34)\end{array}$ & $\begin{array}{l}0.35 \pm 0.008 \\
\quad(0.35)\end{array}$ & $\begin{array}{c}0.0002 \\
\text { G1 vs. G2, G1 vs. G4, G3 vs. } \\
\text { G4 }\end{array}$ & $\begin{array}{l}\text { } 0.0001 \\
\text { G1 vs. G2, G1 vs. G4, G2 vs. } \\
\text { G3, G3 vs. G4 }\end{array}$ & NS \\
\hline McAuley Score & $1.73 \pm 0.38$ & $1.90 \pm 0.27$ & $1.88 \pm 0.27$ & $2.01 \pm 0.22$ & $\begin{array}{c}0.014 \\
\text { G1 vs. G4 }\end{array}$ & $\begin{array}{c}0.006 \\
\text { G1 vs. G4 }\end{array}$ & NS \\
\hline Glycemia/insulin * & $\begin{array}{c}13.86 \pm 5.34 \\
\quad(14.42)\end{array}$ & $\begin{array}{c}12.19 \pm 4.10 \\
\quad(11.60)\end{array}$ & $\begin{array}{l}14.79 \pm 5.5 \\
(13.75)\end{array}$ & $\begin{array}{c}11.79 \pm 1.54 \\
(11.76)\end{array}$ & $\begin{array}{c}0.0076 \\
\text { G1 vs. G2, G1 vs. G4, G2 vs. } \\
\text { G3, G3 vs. G4 }\end{array}$ & 0.06 & NS \\
\hline
\end{tabular}

sICAM1 = soluble Intercellular Adhesion Molecule 1; sVCAM1 = soluble Vascular Adhesion Molecule 1; HOMA index = homeostatic model assessment; Quicki index = quantitative insulin sensitivity check index; ${ }^{*}$ does not respect the normality distribution; for $p$ trend; ANOVA (analysis of variance) or Kruskal-Wallis test was used; NS (not statistically significant) $p>0.05, \mathrm{G} 1=$ group $1, \mathrm{G} 2=$ group $2, \mathrm{G} 3=$ group $3, \mathrm{G} 4=$ group 4 
Significant correlations between adipokines, inflammation molecules, insulin resistance scores, anthropometric measurements, and biochemical parameters for the entire group as well as for the subgroups are presented in Table 4 and Figure 1.

Table 4. Correlations between the parameters (at the global level and at a specific group level).

\begin{tabular}{|c|c|c|c|c|c|c|c|c|c|c|}
\hline & & sICAM1 & sVCAM1 & LEPTIN & GHRELIN & CHEMERIN & HOMA & QUICKI & McAuley Score & GLYC/INS \\
\hline \multirow[t]{5}{*}{ BMI } & Global & 0.045 & $-0.31 *$ & $0.402 * *$ & 0.10 & -0.28 & $0.338^{* *}$ & $\underset{* *}{-0.339}$ & $-0.328 * *$ & 0.11 \\
\hline & G1 & -0.183 & 0.083 & -0.19 & -0.209 & -0.247 & -0.005 & 0.005 & -0.204 & -0.27 \\
\hline & G2 & -0.3 & -0.4 & 0.3 & 0.04 & -0.15 & 0.01 & -0.01 & 0.179 & 0.14 \\
\hline & G3 & $0.75 *$ & 0.107 & 0.02 & -0.17 & 0.39 & 0.18 & -0.18 & 0.139 & 0.39 \\
\hline & G4 & 0.19 & -0.09 & 0.179 & 0.05 & 0.142 & 0.319 * & $-0.33 *$ & $-0.365 *$ & -0.125 \\
\hline \multirow[t]{5}{*}{ WC } & Global & 0.034 & -0.22 & 0.098 & 0.086 & -0.36 & 0.334 ** & $\begin{array}{c}-0.334 \\
* *\end{array}$ & $-0.225 *$ & 0.220 * \\
\hline & G1 & -0.08 & -0.21 & -0.31 & 0.166 & -0.43 & -0.088 & 0.088 & 0.07 & 0.441 \\
\hline & G2 & 0.025 & 0.084 & 0.377 & 0.006 & -0.09 & 0.005 & -0.005 & -0.05 & 0.18 \\
\hline & G3 & 0.306 & -0.306 & -0.493 & -0.134 & 0.11 & 0.128 & -0.128 & 0.398 & 0.604 \\
\hline & G4 & 0.142 & -0.03 & -0.18 & 0.069 & 0.224 & 0.229 & -0.242 & -0.191 & 0.08 \\
\hline \multirow[t]{5}{*}{ TC } & Global & 0.092 & -0.187 & 0.249 & 0.04 & 0.087 & -0.009 & 0.012 & $-0.495 * *$ & -0.14 \\
\hline & G1 & $0.75 *$ & -0.133 & 0.23 & 0.236 & 0.165 & 0.40 & -0.401 & -0.628 * & 0.148 \\
\hline & G2 & 0.517 & -0.033 & 0.667 * & 0.061 & 0.32 & 0.04 & -0.04 & $-0.653^{* *}$ & $-0.512 *$ \\
\hline & G3 & -0.28 & -0.286 & 0.60 & -0.05 & -0.345 & -0.05 & 0.05 & -0.37 & 0.009 \\
\hline & G4 & -0.062 & -0.147 & 0.124 & -0.037 & -0.038 & -0.106 & 0.112 & $-0.514^{* *}$ & -0.08 \\
\hline \multirow[t]{5}{*}{ LDL-C } & Global & 0.133 & -0.145 & -0.140 & 0.004 & 0.042 & 0.05 & -0.49 & $-0.384 * *$ & -0.103 \\
\hline & G1 & 0.603 & -0.293 & 0.036 & 0.124 & 0.047 & 0.316 & -0.316 & -0.536 & 0.206 \\
\hline & G2 & 0.750 * & 0.383 & 0.317 & 0.126 & 0.198 & 0.190 & -0.19 & $-0.629 * *$ & -0.583 * \\
\hline & G3 & -0.179 & -0.429 & 0.771 & -0.03 & -0.255 & -0.023 & 0.023 & -0.17 & 0.182 \\
\hline & G4 & -0.001 & -0.162 & 0.11 & -0.024 & -0.06 & -0.017 & 0.022 & $-0.409^{* *}$ & -0.05 \\
\hline \multirow[t]{5}{*}{ HDL-C } & Global & 0.176 & 0.054 & 0.169 & 0.178 & 0.196 & -0.254 * & $0.256^{*}$ & 0.096 & -0.205 \\
\hline & G1 & $0.795 *$ & 0.059 & 0.503 & 0.515 & 0.454 & 0.263 & -0.263 & -0.338 & 0.069 \\
\hline & G2 & 0.343 & 0.393 & $0.803 * *$ & -0.224 & $0.562 *$ & -0.221 & 0.221 & -0.08 & 0.09 \\
\hline & G3 & -0.286 & 0.01 & 0.314 & 0.330 & -0.40 & -0.2 & 0.20 & -0.08 & 0.05 \\
\hline & G4 & 0.075 & 0.009 & 0.081 & 0.118 & 0.086 & -0.166 & 0.167 & $0.325 *$ & -0.219 \\
\hline \multirow[t]{5}{*}{ TG } & Global & -0.161 & -0.22 & 0.08 & 0.052 & 0.052 & 0.145 & -0.143 & $-0.863 * *$ & -0.06 \\
\hline & G1 & 0.45 & 0.1 & 0.286 & 0.264 & 0.407 & 0.385 & -0.385 & $-0.791 * *$ & -0.038 \\
\hline & G2 & 0.183 & -0.283 & 0.233 & 0.432 & 0.22 & 0.125 & -0.125 & $-0.91^{* *}$ & $-0.677 * *$ \\
\hline & G3 & -0.714 & -0.25 & 0.371 & 0.212 & $-0.582 *$ & 0.291 & -0.291 & $-0.957 * *$ & -0.236 \\
\hline & G4 & -0.295 & -0.129 & -0.08 & -0.175 & 0.021 & -0.017 & 0.026 & $-0.901 * *$ & 0.113 \\
\hline
\end{tabular}

sICAM1 = soluble Intercellular Adhesion Molecule 1; sVCAM1 = soluble Vascular Adhesion Molecule 1; HOMA index = homeostatic model assessment; Quicki index = quantitative insulin sensitivity check index; GLYC/INS = ratio between glycemia and insulin; Spearman coefficient or Pearson coefficient was calculated (depending on distribution type-normal or not); ${ }^{*}$ correlation was significant at the 0.05 level (2-tailed). ${ }^{* *}$ correlation was significant at the 0.01 level (2 tailed). TC $=$ total cholesterol, LDL-C $=$ LDL cholesterol, HDL-C $=$ HDL cholesterol, $\mathrm{TG}=$ triglycerides, $\mathrm{BMI}=$ body mass index, $\mathrm{WC}=$ waist circumference, $\mathrm{G} 1=$ group $1, \mathrm{G} 2=$ group 2, G3 = group 3, $\mathrm{G} 4=$ group 4 .

We found significant correlations across all groups in the sICAM1-sVCAM1 rho $=0.426(p<0.001)$, and in the ghrelin-chemerin rho $=-0.224(p=0.04)$.

We also found the following correlations in each group:

- Group G1 (obesity positive + diabetes positive), in the sICAM1-leptin rho $=0.786(p=0.03)$, sVCAM1-glycemia/insulin rho $=-0.85(p=0.004)$;

- Group G2 (obesity positive + diabetes negative), in the sICAM1-sVCAM1 rho $=0.733(p=0.025)$, and in the sVCAM1-chemerin rho $=0.667(p=0.05)$;

- Group G3 (obesity negative + diabetes positive), no significant correlations;

- Group G4 (obesity negative + diabetes negative), in the sICAM1-HOMA rho $=0.35, p=0.024$, sICAM1-QUICKI rho $=-0.35, p=0.023$, leptin-glycemia/insulin rho $=-0.371 p=0.024$, ghrelin-chemerin rho $=-0.350, p=0.018$, chemerin-HOMA rho $=0.311, p=0.036$, and in the chemerin-QUICKI rho $=-0.31, p=0.036$.

Overall, the subjects with insulin resistance presented greater values of chemerin $-9.05 \pm 5.1 \mathrm{pg} / \mathrm{mL}$ (median value $8.2 \mathrm{pg} / \mathrm{mL}$ ) vs. $8.6 \pm 7.54 \mathrm{pg} / \mathrm{mL}$ (median value $5.6 \mathrm{pg} / \mathrm{mL}$ ) in insulin-sensitive subjects. Even in a small subject sample, the aforementioned relationship was true in G1 (chemerin median value $9.7 \mathrm{pg} / \mathrm{mL}$ in insulin resistant vs. $2.5 \mathrm{pg} / \mathrm{mL}$ in insulin sensitive subjects) and in G4 (16.4 pg/mL vs. $7 \mathrm{pg} / \mathrm{mL})$. 
For chemerin, the greater determined area under the ROC curve was found in group G4 (obesity negative + diabetes negative). A chemerin value $>4.8 \mathrm{pg} / \mathrm{mL}$ was capable to identify the HOMA index $>2$ subjects with a $\mathrm{Se}=100 \%, \mathrm{Sp}=46.3 \%$, area under the ROC $(\mathrm{AUROC})=0.688$ (in women, AUROC $=0.719$; however, we were not able to perform the test with the men, due to the small sample size of male subjects). The prediction capacity was better in G4 (AUROC $=0.688, \mathrm{Sp}=46.3 \%$ ) vs. the entire sample (AUROC $=0.508, \mathrm{Sp}=19.05 \%)$.

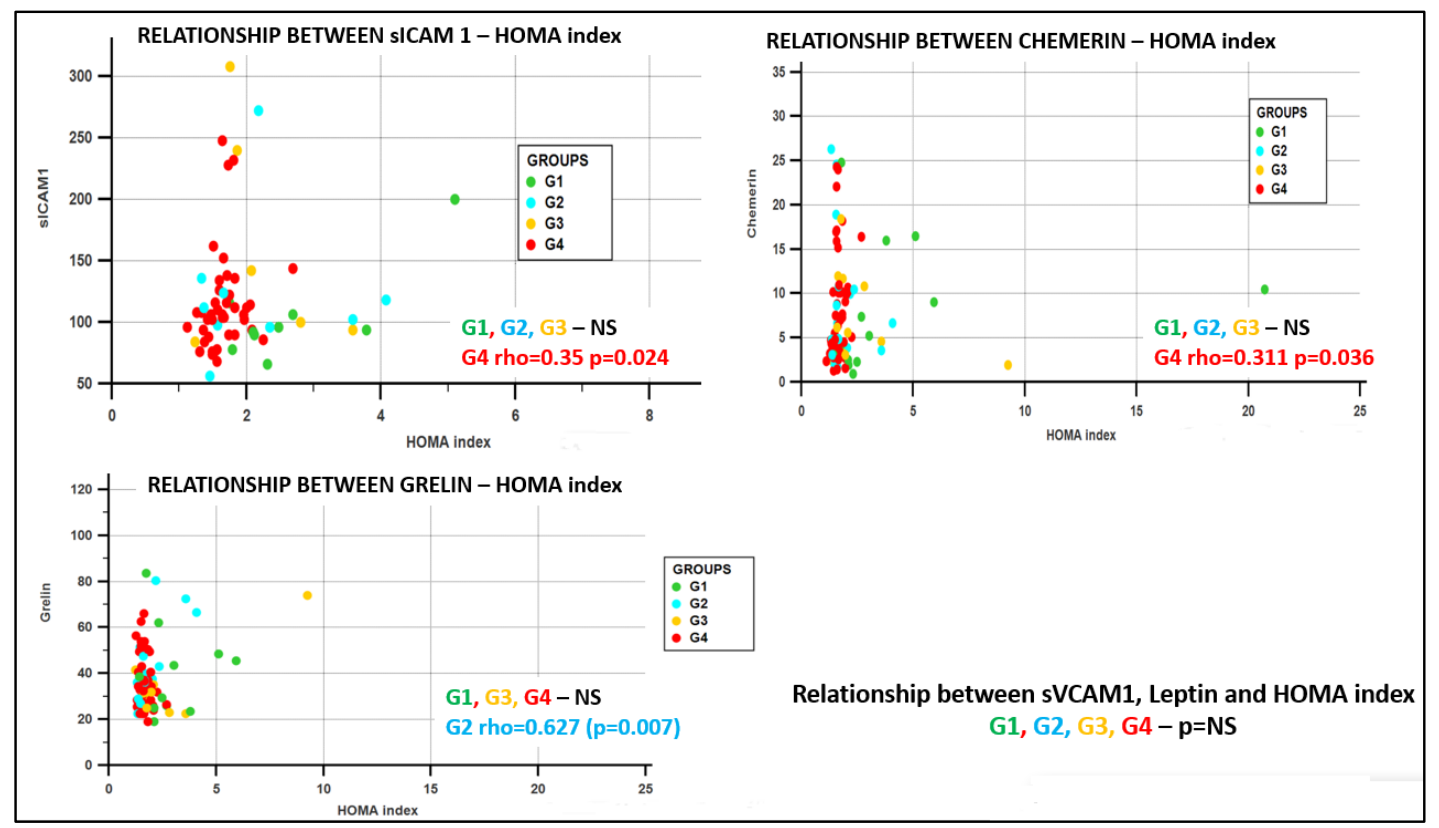

Figure 1. Relationship between the HOMA index (homeostatic model assessment) and adhesion molecules and adipokines. Panel a: relationship between sICAM1 (soluble Intercellular Adhesion Molecule 1) and HOMA index depending on the subjects' groups; panel b: relationship between chemerin and HOMA index depending on the subjects' groups; panel c: relationship between ghrelin and HOMA index depending on the subjects' groups.

\section{Discussion}

The adoption of the Western European diet and other similar lifestyle changes have caused an unfortunate increase in cases of diabetes and obesity. This change has had significant consequences for the overall health of the population and increased the financial burden on our health systems. In many cases, the diagnosis of T2DM is late, and patients have already developed complications from the illness [28].

As is currently well known, adipose tissue itself represents an endocrine organ [29-32]. Recent studies have shown that obesity and the increase in the size and number of adipocytes are associated with an alteration of lipid and carbohydrate metabolism [31,33,34], insulin resistance and systemic inflammation [33]. Adipose tissue causes these changes through the secretion of biologically active molecules: over 600 adipokines (such as leptin, resistin, apelin, vaspin, omentin, visfatin, adiponectin, chemerin, etc.), cytokines, both pro-inflammatory and anti-inflammatory, interleukinsIL (IL1, IL6), chemokines (IL8, MCP 1- monocye chemoattractant protein-1), vasoactive substances, interferon, and hormone-like action proteins [29-35]. The increase in the level of proatherogenic substances, with a pro-inflammatory effect, might trigger a cascade of insulin resistance [34], as well as the relationship between obesity and diabetes and vascular complications, respectively [34]. However, to date there are no data to explain the exact chronology of this process [34].

In the development of atherosclerotic vascular damage induced by obesity or diabetes, endothelial dysfunction occurs at an early, subclinical stage [36] by activating inflammation and initiating 
the adhesion cell expression [37]. There are still many controversies surrounding the methods of quantifying early endothelial dysfunction (including a genetic evaluation to identify potential risk) [38]. The assessment of the role of adhesion molecules is questioned [37]. Previous studies have shown that the family of adhesion molecules is extremely heterogeneous. While sICAM1 is expressed in endothelial cells (with low levels detected even when there are no alterations of these) [39], smooth muscle cells, and epithelial cells, sVCAM1 is an indicator of plaque activity (being detected only in endothelial cells) $[37,39]$.

An increase in the levels of sICAM1 and sVCAM1 was evidenced in patients with insulin resistance [40], and in those who will later develop [41,42] or already present diabetes $[40,43,44]$. sICAM1 values are generally higher in women with insulin resistance vs. men [39]. In this study, of the two adhesion molecules, sICAM1 was correlated with insulin resistance indices, but only in G4 (O-D-). No significant differences in the sICAM1 values between groups were found. Regarding sVCAM1, diabetic subjects with obesity had significantly higher values compared to normal weight subjects (G1 vs. G3, $p<0.05$ ). Both overall and in the case of analysis by groups, significant correlations were detected between the values of two adhesion molecules, similarly to previously reported data $[39,45]$.

Leptin (the first adipocyte hormone identified), is a 167 amino acid hormone secreted by adipose tissue. It has an influence on dietary intake [14,24], body weight, and adipose deposits [30] through a direct effect on the hypothalamus [34], which induces the sensation of satiety [35]. Leptin has pro-inflammatory activity (activation of macrophages, $\mathrm{T}$ and NK cells, the release of cytokines, interleukins IL6 and IL12 [30,35]), while simultaneously playing a role in endothelial cell proliferation and migration [46], platelet aggregation [46], and promotion of endothelial dysfunction (stimulation of the release of adhesion molecules, M-CSF (macrophage colony-stimulating factor), promotion of cholesterol accumulation, angiogenesis [30] and atherogenesis). Obese patients have increased serum levels (due to increased secretion from the adipose tissue), proportional to insulin levels [30], while leptin resistance develops over time [30,34]. According to the literature [47], higher leptin levels were found in women than in men, and the presence of obesity (associated or not with the presence of diabetes mellitus) determined significantly higher values of serum leptin in both genders. In group G1, we detected a correlation between the levels of leptin and adhesion molecules, which evidenced significant inflammation present in these conditions.

Ghrelin, a stomach-derived hormone (produced by X/A-like cells within the gastric oxyntic glands of the stomach) [3], is a key player in the regulation of appetite and energy homeostasis [48]. It is also involved in glucose metabolism and homeostasis [48], insulin sensitivity, in the development of diabetes [49,50], and in adipogenesis [49]. Ghrelin is considered to play a bimodal role, initially proatherogenic (in the early formation of plaques), and later antiatherogenic (as the atherosclerotic disease progresses) [49]. It may also have pro-inflammatory and anti-inflammatory properties [49] and protective effects on the heart [3].

Ghrelin secretion shows an alteration of the physiological pattern in patients with insulin resistance or obesity [48]. Low ghrelin levels have been recorded in diabetic patients [49] as well as in obese patients $[48,51-54]$. The literature advances the idea that secretion would be inhibited by hyperinsulinemia and hyperleptinemia [52]. Low ghrelin levels are associated with unfavorable prognosis and increased global cardiovascular risk [52]. This study found no significant differences between the four groups (probably due to the bimodal role); surprisingly, obese non-diabetic subjects had high serum ghrelin levels. In group G2, ghrelin was significantly correlated with insulin resistance.

Chemerin, a recently discovered adipokine [55] (also known as tazarotene-induced gene 2 (TIG2) and retinoic acid receptor responder 2 (RARRES2) [31]) is a 163 amino acid pre-proprotein that is secreted as a 143 amino acid (18 $\mathrm{kDa})$ proprotein and subsequently undergoes C-terminal cleavage [32,33]. It has recently been discovered that chemerin has at least three receptors: $G$ protein-coupled receptor CMKLR1 (chemokine-like receptor 1 or ChemR23), G protein-coupled receptor 1 (GPR1) and (C-C motif) receptor-like (CCRL) 2 [56-58]. CMKLR1 is expressed mainly in adipose tissue (higher levels in white compared to brown adipose tissue), bone, lung, brain, heart, and placenta [55,59]. Chemerin binds to 
orphan CMKLR1 [24,60], activates the three G $\alpha$ i subtypes, and the two G $\alpha$ o isoform [56], exercising in this way main biological functions [57,60]. CMKLR1 activation is responsible for intracellular calcium release and a reduction in cAMP (cyclic adenosine monophosphate) accumulation [59]. On the other hand, a loss of CMKLR1 has been reported to be associated with reduced body mass and adiposity [59,61], and its upregulation is found in obese patients [56].

Chemerin plays a role in adipogenesis $[6,8,29,55,56,62]$, preadipocyte differentiation, adipocyte development and metabolism [29,31,57,63-65], insulin sensitivity [6,56], and in lipid and glucose metabolism $[29,55,58,66,67]$. It is a pro-inflammatory agent $[8,16,33,55,65]$, a chemoattractant for various types of cells $[8,16,33,64,65]$, and modulates immune system function [31,56].

Initially, it was believed that the secretion of chemerin increases significantly in parallel to adipogenesis. It was assumed that the alteration of this process, or the change in the expression of the chemerin receptor CMKLR1 or chemerin-CMKLR1 signaling, affected adipocyte differentiation $[7,56,68,69]$, impaired glucose homeostasis [70] and glucose-stimulated pancreatic insulin release [7], affected insulin sensitivity [71], and even modified the genes involved in lipid and glucose metabolism [7]. Recently, given chemerin's multiple roles, a new hypothesis was formed-chemerin itself can be a link between inflammation, obesity and atherosclerosis [72].

The data published to date reflect the fact that serum chemerin values are correlated with body mass index, serum triglyceride levels and inversely with HDL cholesterol values $[29,31,33,55,62,67,73-75]$. In addition, it was reported that elderly people had higher chemerin values [31,73,74], but without significant differences depending on the patients' gender [31,76]. This study found no significant differences depending on the subjects' sex either.

The relationship between the chemerin and insulin resistance/insulin sensitivity is not completely understood; some studies report a direct association with insulin resistance [62,67,74,77-82], while others refute it, saying that chemerin is actually involved in the regulation of insulin sensitivity $[7,55,65,83,84]$. At the same time, the information reported to date regarding the relationship between chemerin values and the presence of obesity or diabetes is contradictory. There are data referring to the increase in serum chemerin values in obese patients $[6,24,29,55,56,58,62,64,72,75,85]$, in obese non-diabetic patients $[75,86]$, in diabetic patients $[24,29,55,58,64,74,80,83,85,87]$, in obese diabetic patients [81], and in patients with metabolic syndrome [31,78]. On the other hand, some studies highlight the absence of changes in chemerin values [88] or even their decrease in diabetic patients [63], or the absence of significant differences between obese and non-obese diabetic patients [74].

The reasons for these discrepancies are under evaluation. The expression of chemerin might be related to a threshold between adipogenesis and inflammation. During early adipogenesis, chemerin promotes insulin sensitivity, but increased adipogenesis during obesity makes chemerin release proinflammatory cytokines.

In our study, in the group of non-diabetic non-obese subjects, there was a positive correlation between chemerin and the HOMA index. This finding supports the previously mentioned idea that chemerin might be an early marker of insulin resistance, as it is capable of predicting the development of metabolic syndrome [16] or diabetes [7,79,87], detecting the alteration of insulin sensitivity $[49,50,66]$, and discriminating subjects with subclinical diabetes $[66,89]$. The best predictive capacity for insulin resistance was also found in the non-diabetic non-obese group.

In time, increased inflammation leads to insulin resistance and subsequent diabetes. Even if the clinical onset of diabetes is preceded by the development of insulin resistance, this is extremely difficult to quantify, so identifying early markers might be a key step in the management of diabetes.

Moreover, it must be considered that not all obese patients have insulin resistance (about 25\% of obese subjects are insulin sensitive, being classified, as we mentioned, into metabolically healthy obese) $[9,82,90]$, and remain insulin-sensitive for a period $[9,91]$. These MHO patients seem to present lower chemerin levels vs. MUO patients [16]. This is in accordance with our findings that registered chemerin values are lower in obese-diabetic patients with lower values of the HOMA index. 
It should be mentioned that serum chemerin values can also be influenced by the medication that a patient is taking. Some published studies $[79,92]$ reported the fact that pioglitazone and metformin (most likely due to increased insulin sensitivity) [93] caused a decrease in serum chemerin values in patients with T2DM. In the studied group, patients with T2DM did not show higher chemerin values, which might be attributed to the aforementioned influence of medication (unfortunately, relevant information about the medication administered to the investigated subjects was not collected).

The interactions between different adipokines create a complex picture, with various interrelations and the effects of adipokines being both synergistic and antagonistic. Previous studies evidence a correlation between chemerin and leptin levels [33,74], as well as between chemerin and markers of systemic inflammation (C-reactive protein, interleukin 6, and TNF alpha) $[33,66,67,74,94]$. We did not detect a correlation between chemerin and leptin, but depending on the studied subgroup, chemerin was correlated with sVCAM1. To the best of our knowledge, there are no reported data regarding the relationship between chemerin and ghrelin. We found that the study subjects as a whole showed a significant inverse correlation between chemerin and ghrelin, which was maintained in G4 (subclinical changes and early insulin resistance caused an early increase in chemerin and a decrease in ghrelin).

By synthesizing the presented data, we can advance the hypothesis, supported by other authors $[33,57,87]$, that chemerin is a possible link between obesity-inflammation-diabetes-atherosclerosis, and that its release could be much earlier than that of other adipokines.

Limitations of the study include the small number of subjects. We also have to mention the discrepancy between the number of women and the number of men. Our subjects were consecutive hospital patients who met our criteria, so our control over the diversity of subjects was limited. Further studies are necessary to quantify the influence of the subjects' gender on adipokines-obesity-diabetes interaction. To at least partially support our results (in both genders), we want to mention the fact that no significant differences were found between the genders regarding metabolic syndrome features (including insulin resistance/sensitivity scores), with the only exception of the lipid profile (HDL cholesterol). Furthermore, due to the small number of subjects, we were unable to investigate how obesity or gender might influence chemerin behavior. Our data did not allow us to study how a patient's medication might influence insulin resistance, either.

The current study opens new research directions to identify changes in "active molecules" as early as possible, which would not only allow early diagnosis, but especially the prevention of certain diseases.

In conclusion, there are still many questions surrounding the release and the role of various adipokines, in particular chemerin. During early adipogenesis, it is possible for chemerin to promote insulin sensitivity and to provide useful information regarding the early diagnostic of glucose metabolism dysregulation disorders.

Author Contributions: Conceptualization, A.-V.S.-T. and A.C.; methodology, A.-V.S.-T., A.C.; software, A.-V.S.-T., C.L.; validation, S.C.C., S.T., O.H.O.; investigation, A.-V.S.-T.; O.H.O.; data curation, S.C.C.; A.F., O.H.O., B.T., C.L.; writing—original draft preparation, A.-V.S.-T.; S.C.C., S.T., O.H.O.; writing-review and editing, A.-V.S.-T., V.N., D.P., D.Z., A.C.; visualization, A.C.; supervision, A.-V.S.-T.; A.C. All authors have read and agreed to the published version of the manuscript.

Funding: This research received no external funding.

Conflicts of Interest: The authors declare no conflict of interest.

\section{References}

1. Romacho, T.; Elsen, M.; Röhrborn, D.; Eckel, J. Adipose tissue and its role in organ crosstalk. Acta Physiol. 2014, 210, 733-753. [CrossRef] [PubMed]

2. Bergmann, K.; Sypniewska, G. Diabetes as a complication of adipose tissue dysfunction. Is there a role for potential new biomarkers? Clin. Chem. Lab. Med. 2013, 51, 177-185. [CrossRef] [PubMed] 
3. Poher, A.L.; Tschöp, M.H.; Müller, T.D. Ghrelin regulation of glucose metabolism. Peptides 2018, 100, $236-242$. [CrossRef] [PubMed]

4. Kim, W.K.; Bae, K.-H.; Lee, S.C.; Oh, K.-J. The latest insights into adipokines in diabetes. J. Clin. Med. 2019, 8, 1874. [CrossRef] [PubMed]

5. Gelsinger, C.; Tschoner, A.; Kaser, S.; Ebenbichler, C.F. Adipokine update-Neue moleküle, neue funktionen. Wien. Med. Wochenschr. 2010, 160, 377-390. [CrossRef]

6. Spyrou, N.; Avgerinos, K.I.; Mantzoros, C.S.; Dalamaga, M. Classic and novel adipocytokines at the intersection of obesity and cancer: Diagnostic and therapeutic strategies. Curr. Obes. Rep. 2018, 7, 260-275. [CrossRef]

7. Roman, A.A.; Parlee, S.D.; Sinal, C.J. Chemerin: A potential endocrine link between obesity and type 2 diabetes. Endocrine 2012, 42, 243-251. [CrossRef]

8. Dagpo, T.D.; Nolan, C.J.; Delghingaro-Augusto, V. Exploring therapeutic targets to reverse or prevent the transition from metabolically healthy to unhealthy obesity. Cells 2020, 9, 1596. [CrossRef]

9. Chait, A.; den Hartigh, L.J. Adipose tissue distribution, inflammation and its metabolic consequences, including diabetes and cardiovascular disease. Front. Cardiovasc. Med. 2020, 7, 1-41. [CrossRef]

10. Internation diabetes federation. IDF Diabetes Atlas Ninth. 2019. ISBN 9782930229874. Available online: https://www.diabetesatlas.org/en/ (accessed on 20 May 2020).

11. Weinstein, A.R.; Sesso, H.D.; Lee, I.M.; Cook, N.R.; Manson, J.A.E.; Buring, J.E.; Gaziano, J.M. Relationship of physical activity vs body mass index with type 2 diabetes in women. J. Am. Med. Assoc. 2004, 292, 1188-1194. [CrossRef]

12. Vinciguerra, F.; Tumminia, A.; Baratta, R.; Ferro, A.; Alaimo, S.; Hagnäs, M.; Graziano, M.; Vigneri, R.; Frittitta, L. Prevalence and clinical characteristics of children and adolescents with metabolically healthy obesity: Role of insulin sensitivity. Life 2020, 10, 127. [CrossRef] [PubMed]

13. Ambele, M.A.; Dhanraj, P.; Giles, R.; Pepper, M.S. Adipogenesis: A complex interplay of multiple molecular determinants and pathways. Int. J. Mol. Sci. 2020, 21, 4283. [CrossRef] [PubMed]

14. Kojta, I.; Chacińska, M.; Błachnio-Zabielska, A. Obesity, bioactive lipids, and adipose tissue inflammation in insulin resistance. Nutrients 2020, 12, 1305. [CrossRef] [PubMed]

15. Yeh, T.-L.; Chen, H.-H.; Tsai, S.-Y.; Lin, C.-Y.; Liu, S.-J.; Chien, K.-L. The relationship between metabolically healthy obesity and the risk of cardiovascular disease: A systematic review and meta-analysis. J. Clin. Med. 2019, 8, 1228. [CrossRef]

16. Catoi, A.; Parvu, A.; Andreicut, A.; Mironiuc, A.; Craciun, A.; Catoi, C.; Pop, I. Metabolically healthy versus unhealthy morbidly obese: Chronic inflammation, nitro-oxidative stress, and insulin resistance. Nutrients 2018, 10, 1199. [CrossRef]

17. Eckel, N.; Meidtner, K.; Kalle-Uhlmann, T.; Stefan, N.; Schulze, M.B. Metabolically healthy obesity and cardiovascular events: A systematic review and meta-analysis. Eur. J. Prev. Cardiol. 2015, 23, 956-966. [CrossRef]

18. Hamer, M.; Stamatakis, E. Metabolically healthy obesity and risk of all-cause and cardiovascular disease mortality. J. Clin. Endocrinol. Metab. 2012, 97, 2482-2488. [CrossRef]

19. Funcke, J.B.; Scherer, P.E. Beyond adiponectin and leptin: Adipose tissue-derived mediators of inter-organ communication. J. Lipid Res. 2019, 60, 1648-1697. [CrossRef]

20. Unamuno, X.; Gómez-Ambrosi, J.; Rodríguez, A.; Becerril, S.; Frühbeck, G.; Catalán, V. Adipokine dysregulation and adipose tissue inflammation in human obesity. Eur. J. Clin. Investig. 2018, 48, 1-11. [CrossRef]

21. Barchetta, I.; Cimini, F.A.; Ciccarelli, G.; Baroni, M.G.; Cavallo, M.G. Sick fat: The good and the bad of old and new circulating markers of adipose tissue inflammation. J. Endocrinol. Investig. 2019, 42, 1257-1272. [CrossRef]

22. Jung, U.J.; Choi, M. Obesity and its metabolic complications: The role of adipokines and the relationship between obesity, inflammation, insulin resistance, dyslipidemia and nonalcoholic fatty liver disease. Int. J. Mol. Sci. 2014, 15, 6184-6223. [CrossRef] [PubMed]

23. Chehimi, M.; Vidal, H.; Eljaafari, A. Pathogenic role of IL-17-producing immune cells in obesity, and related inflammatory diseases. J. Clin. Med. 2017, 6, 68. [CrossRef] [PubMed]

24. Lee, M.-W.; Lee, M.; Oh, K.-J. Adipose tissue-derived signatures for obesity and type 2 diabetes: Adipokines, batokines and MicroRNAs. J. Clin. Med. 2019, 8, 854. [CrossRef] [PubMed] 
25. Cozma, A.; Sitar-Taut, A.-V.; Fodor, A.; Oltean, M.; Minciuna, I.-A.; Breaban, I.; Matuz, R.; Racataianu, N.; Dogaru, G.; Orăşan, O. Evaluation of endothelial dysfunction and its improvement after cardiac rehabilitation. Balneo Res. J. 2018, 9, 364-375. [CrossRef]

26. Cosentino, F.; Grant, P.J.; Aboyans, V.; Bailey, C.J.; Ceriello, A.; Delgado, V.; Federici, M.; Filippatos, G.; Grobbee, D.E.; Hansen, T.B.; et al. 2019 ESC Guidelines on diabetes, pre-diabetes, and cardiovascular diseases developed in collaboration with the EASD. Eur. Heart J. 2020, 41, 255-323. [CrossRef]

27. Mach, F.; Baigent, C.; Catapano, A.L.; Koskinas, K.C.; Casula, M.; Badimon, L.; Chapman, M.J.; de Backer, G.G.; Delgado, V.; Ference, B.A.; et al. 2019 ESC/EAS Guidelines for the management of dyslipidaemias: Lipid modification to reduce cardiovascular risk. Eur. Heart J. 2020, 41, 111-188. [CrossRef]

28. Albu, A.; Para, I. Left ventricular diastolic dysfunction in diabetes mellitus and the therapeutic role of exercise training. Balneo Res. J. 2019, 10, 145-152. [CrossRef]

29. Gateva, A.; Assyov, Y.; Tsakova, A.; Kamenov, Z. Classical (adiponectin, leptin, resistin) and new (chemerin, vaspin, omentin) adipocytokines in patients with prediabetes. Horm. Mol. Biol. Clin. Investig. 2018, 34, 1-9. [CrossRef]

30. Wozniak, S.E.; Gee, L.L.; Wachtel, M.S.; Frezza, E.E. Adipose tissue: The new endocrine organ? A review article. Dig. Dis. Sci. 2009, 54, 1847-1856. [CrossRef]

31. Stejskal, D.; Karpisek, M.; Hanulova, Z.; Svestak, M. Chemerin is an independent marker of the metabolic syndrome in a Caucasian population-A pilot study. Biomed. Pap. Med. Fac. Univ. Palacky. Olomouc. Czech. Repub. 2008, 152, 217-221. [CrossRef]

32. Stojek, M. The role of chemerin in human disease. Postepy Hig. Med. Dosw. 2017, 71, 110-117. [CrossRef] [PubMed]

33. Ernst, M.C.; Sinal, C.J. Chemerin: At the crossroads of inflammation and obesity. Trends Endocrinol. Metab. 2010, 21, 660-667. [CrossRef]

34. Calabrò, P.; Golia, E.; Maddaloni, V.; Malvezzi, M.; Casillo, B.; Marotta, C.; Calabrò, R.; Golino, P. Adipose tissue-mediated inflammation: The missing link between obesity and cardiovascular disease? Intern. Emerg. Med. 2009, 4, 25-34. [CrossRef] [PubMed]

35. Reddy, P.; Lent-Schochet, D.; Ramakrishnan, N.; McLaughlin, M.; Jialal, I. Metabolic syndrome is an inflammatory disorder: A conspiracy between adipose tissue and phagocytes. Clin. Chim. Acta 2019, 496, 35-44. [CrossRef] [PubMed]

36. Aizawa, K.; Shoemaker, J.K.; Overend, T.J.; Petrella, R.J. Metabolic syndrome, endothelial function and lifestyle modification. Diab. Vasc. Dis. Res. 2009, 6, 181-189. [CrossRef]

37. Schram, M.T.; Stehouwer, C.D.A. Endothelial dysfunction, cellular adhesion molecules and the metabolic syndrome. Horm. Metab. Res. 2005, 37 (Suppl. 1), 49-55. [CrossRef]

38. Cozma, A.; Sitar-Taut, A.-V.; Orasan, O.; Procopciuc, L.M.; Farcas, A.D.; Stan, A.; Negrean, V.; Sampelean, D.; Pop, D.; Zdrenghea, D.; et al. The relationship between eNOS (G894T) gene polymorphism and arterial stiffness in patients with metabolic syndrome. Rev. Chim. 2018, 69, 2351-2356. [CrossRef]

39. Sitar-Taut, A.V.; Orasan, O.; Fodor, A.; Farcas, A.D.; Tarmure Sarlea, S.T.; Dogaru, G.; Zdrenghea, D.T.; Pop, D.; Cozma, A. The relationship between inflammation and metabolic syndrome (METS)-A matter of gender? Rev. Chim. 2019, 70, 69-73. [CrossRef]

40. Song, Y.; Manson, J.E.; Tinker, L.; Rifai, N.; Cook, N.R.; Hu, F.B.; Hotamisligil, G.S.; Ridker, P.M.; Rodriguez, B.L.; Margolis, K.L.; et al. Circulating levels of endothelial adhesion molecules and risk of diabetes in an ethnically diverse cohort of women. Diabetes 2007, 56, 1898-1904. [CrossRef]

41. Sattar, N.; Murray, H.M.; Welsh, P.; Blauw, G.J.; Buckley, B.M.; de Craen, A.J.; Ford, I.; Forouhi, N.G.; Freeman, D.J.; Jukema, J.W.; et al. Are elevated circulating intercellular adhesion molecule 1 levels more strongly predictive of diabetes than vascular risk? Outcome of a prospective study in the elderly. Diabetologia 2009, 52, 235-239. [CrossRef]

42. Thorand, B.; Baumert, J.; Chambless, L.; Meisinger, C.; Kolb, H.; Döring, A.; Löwel, H.; Koenig, W. Elevated markers of endothelial dysfunction predict type 2 diabetes mellitus in middle-aged men and women from the general population. Arterioscler. Thromb. Vasc. Biol. 2006, 26, 398-405. [CrossRef] [PubMed]

43. Rubio-Guerra, A.F.; Vargas-Robles, H.; Lozano Nuevo, J.J.; Escalante-Acosta, B.A. Correlation between circulating adhesion molecule levels and albuminuria in type-2 diabetic hypertensive patients. Kidney Blood Press. Res. 2009, 32, 106-109. [CrossRef] 
44. de Marañón, A.M.; Iannantuoni, F.; Abad-Jiménez, Z.; Canet, F.; Díaz-Pozo, P.; López-Domènech, S.; Roldán-Torres, I.; Morillas, C.; Rocha, M.; Víctor, V.M. Association between proinflammatory markers, leukocyte-endothelium interactions, and carotid intima-media thickness in type 2 diabetes: Role of glycemic control. J. Clin. Med. 2020, 9, 2522. [CrossRef] [PubMed]

45. Ingelsson, E.; Hulthe, J.; Lind, L. Inflammatory markers in relation to insulin resistance and the metabolic syndrome. Eur. J. Clin. Investig. 2008, 38, 502-509. [CrossRef] [PubMed]

46. Antuna-Puente, B.; Feve, B.; Fellahi, S.; Bastard, J.-P. Adipokines: The missing link between insulin resistance and obesity. Diabetes Metab. 2008, 34, 2-11. [CrossRef] [PubMed]

47. Lago, F.; Gómez, R.; Gómez-Reino, J.J.; Dieguez, C.; Gualillo, O. Adipokines as novel modulators of lipid metabolism. Trends Biochem. Sci. 2009, 34, 500-510. [CrossRef]

48. Alamri, B.N.; Shin, K.; Chappe, V.; Anini, Y. The role of ghrelin in the regulation of glucose homeostasis. Horm. Mol. Biol. Clin. Investig. 2016, 26, 3-11. [CrossRef]

49. Kadoglou, N.P.E.; Lampropoulos, S.; Kapelouzou, A.; Gkontopoulos, A.; Theofilogiannakos, E.K.; Fotiadis, G.; Kottas, G. Serum levels of apelin and ghrelin in patients with acute coronary syndromes and established coronary artery disease-KOZANI STUDY. Transl. Res. 2010, 155, 238-246. [CrossRef]

50. Kadoglou, N.P.E.; Tsanikidis, H.; Kapelouzou, A.; Vrabas, I.; Vitta, I.; Karayannacos, P.E.; Liapis, C.D.; Sailer, N. Effects of rosiglitazone and metformin treatment on apelin, visfatin, and ghrelin levels in patients with type 2 diabetes mellitus. Metabolism 2010, 59, 373-379. [CrossRef]

51. Ukkola, O. Ghrelin and metabolic disorders. Curr. Protein Pept. Sci. 2009, 10, 2-7. [CrossRef]

52. Pop, D.; Peter, P.; Dădârlat, A.; Sitar-Tăut, A.; Zdrenghea, D. Serum ghrelin level is associated with cardiovascular risk score. Rom. J. Intern. Med. 2015, 53, 140-145. [CrossRef] [PubMed]

53. Razzaghy-Azar, M.; Nourbakhsh, M.; Pourmoteabed, A.; Nourbakhsh, M.; Ilbeigi, D.; Khosravi, M. An evaluation of acylated ghrelin and obestatin levels in childhood obesity and their association with insulin resistance, metabolic syndrome, and oxidative stress. J. Clin. Med. 2016, 5, 61. [CrossRef]

54. Pop, D.; Sitar-Taut, A.; Bodisz, G.; Dadarlat, A.; Stanca, L.; Buzoianu, A.; Zdrenghea, D. Are ghrelin levels directly related with ishemic heart disease. Ind. J. Res. 2013, 2, 222-224.

55. Helfer, G.; Wu, Q.F. Chemerin: A multifaceted adipokine involved in metabolic disorders. J. Endocrinol. 2018, 238, R79-R94. [CrossRef] [PubMed]

56. Buechler, C.; Feder, S.; Haberl, E.M.; Aslanidis, C. Chemerin isoforms and activity in obesity. Int. J. Mol. Sci. 2019, 20, 1128. [CrossRef] [PubMed]

57. Kaur, J.; Mattu, H.S.; Chatha, K.; Randeva, H.S. Chemerin in human cardiovascular disease. Vascul. Pharmacol. 2018, 110, 1-6. [CrossRef]

58. Perumalsamy, S.; Aqilah Mohd Zin, N.A.; Widodo, R.T.; Wan Ahmad, W.A.; Vethakkan, S.R.D.B.; Huri, H.Z. Chemokine like receptor-1 (CMKLR-1) receptor: A Potential therapeutic target in management of chemerin induced type 2 diabetes mellitus and cancer. Curr. Pharm. Des. 2017, 23, 3689-3698. [CrossRef]

59. Rourke, J.L.; Dranse, H.J.; Sinal, C.J. Towards an integrative approach to understanding the role of chemerin in human health and disease. Obes. Rev. 2013, 14, 245-262. [CrossRef]

60. Estienne, A.; Reverchon, M.; Partyka, A.; Bourdon, G.; Grandhaye, J.; Barbe, A.; Caldas-Silveira, E.; Rame, C.; Niżański, W.; Froment, P.; et al. Chemerin impairs in vitro testosterone production, sperm motility, and fertility in chicken: Possible involvement of its receptor CMKLR1. Cells 2020, 9, 1599. [CrossRef]

61. Ernst, M.C.; Haidl, I.D.; Zuñĩga, L.A.; Dranse, H.J.; Rourke, J.L.; Zabel, B.A.; Butcher, E.C.; Sinal, C.J. Disruption of the chemokine-like receptor-1 (CMKLR1) gene is associated with reduced adiposity and glucose intolerance. Endocrinology 2012, 153, 672-682. [CrossRef]

62. Karczewska-Kupczewska, M.; Nikolajuk, A.; Stefanowicz, M.; Matulewicz, N.; Kowalska, I.; Straczkowski, M. Serum and adipose tissue chemerin is differentially related to insulin sensitivity. Endocr. Connect. 2020,9, 360-369. [CrossRef] [PubMed]

63. Takahashi, M.; Inomata, S.; Okimura, Y.; Iguchi, G.; Fukuoka, H.; Miyake, K.; Koga, D.; Akamatsu, S.; Kasuga, M.; Takahashi, Y. Decreased serum chemerin levels in male Japanese patients with type 2 diabetes: Sex dimorphism. Endocr. J. 2013, 60, 37-44. [CrossRef] [PubMed]

64. Roguska, J.; Zubkiewicz-Kucharska, A. Chemerin as an early marker of metabolic syndrome. Pediatr. Endocrinol. Diabetes Metab. 2018, 24, 43-49. [CrossRef] [PubMed]

65. Park, S.E.; Park, C.Y.; Sweeney, G. Biomarkers of insulin sensitivity and insulin resistance: Past, present and future. Crit. Rev. Clin. Lab. Sci. 2015, 52, 180-190. [CrossRef] [PubMed] 
66. Fatima, S.S.; Butt, Z.; Bader, N.; Pathan, A.Z.; Hussain, S.; Iqbal, N.T. Role of multifunctional chemerin in obesity and preclinical diabetes. Obes. Res. Clin. Pract. 2015, 9, 507-512. [CrossRef]

67. Han, J.; Kim, S.H.; Suh, Y.J.; Lim, H.A.; Shin, H.; Cho, S.G.; Kim, C.W.; Lee, S.Y.; Lee, D.H.; Hong, S.; et al. Serum chemerin levels are associated with abdominal visceral fat in type 2 diabetes. J. Korean Med. Sci. 2016, 31, 924-931. [CrossRef]

68. Goralski, K.B.; McCarthy, T.C.; Hanniman, E.A.; Zabel, B.A.; Butcher, E.C.; Parlee, S.D.; Muruganandan, S.; Sinal, C.J. Chemerin, a novel adipokine that regulates adipogenesis and adipocyte metabolism. J. Biol. Chem. 2007, 282, 28175-28188. [CrossRef]

69. MacDougald, O.A.; Burant, C.F. The rapidly expanding family of adipokines. Cell Metab. 2007, 6, 159-161. [CrossRef]

70. Huang, C.; Wang, M.; Ren, L.; Xiang, L.; Chen, J.; Li, M.; Xiao, T.; Ren, P.; Xiong, L.; Zhang, J.V. CMKLR1 deficiency influences glucose tolerance and thermogenesis in mice on high fat diet. Biochem. Biophys. Res. Commun. 2016, 473, 435-441. [CrossRef]

71. Corona-Meraz, F.-I.; Navarro-Hernández, R.-E.; Ruíz-Quezada, S.-L.; Madrigal-Ruíz, P.-M.; Castro-Albarrán, J.; Chavarría-Ávila, E.; Guzmán-Ornelas, M.-O.; Gómez-Bañuelos, E.; Petri, M.-H.; Ramírez-Cedano, J.-I.; et al. Inverse relationship of the CMKLR1 relative expression and chemerin serum levels in obesity with dysmetabolic phenotype and insulin resistance. Mediators Inflamm. 2016, 2016. [CrossRef]

72. Niklowitz, P.; Rothermel, J.; Lass, N.; Barth, A.; Reinehr, T. Link between chemerin, central obesity, and parameters of the Metabolic Syndrome: Findings from a longitudinal study in obese children participating in a lifestyle intervention. Int. J. Obes. 2018, 42, 1743-1752. [CrossRef]

73. Coimbra, S.; Brandão Proença, J.; Santos-Silva, A.; Neuparth, M.J. Adiponectin, leptin, and chemerin in elderly patients with type 2 diabetes mellitus: A close linkage with obesity and length of the disease. Biomed. Res. Int. 2014, 2014, 701915. [CrossRef] [PubMed]

74. Habib, S.S.; Eshki, A.; AlTassan, B.; Fatani, D.; Helmi, H.; AlSaif, S. Relationship of serum novel adipokine chemerin levels with body composition, insulin resistance, dyslipidemia and diabesity in Saudi women. Eur. Rev. Med. Pharmacol. Sci. 2017, 21, 1296-1302.

75. Bozaoglu, K.; Segal, D.; Shields, K.A.; Cummings, N.; Curran, J.E.; Comuzzie, A.G.; Mahaney, M.C.; Rainwater, D.L.; Vandeberg, J.L.; MacCluer, J.W.; et al. Chemerin is associated with metabolic syndrome phenotypes in a Mexican-American population. J. Clin. Endocrinol. Metab. 2009, 94, 3085-3088. [CrossRef] [PubMed]

76. Fatima, S.S.; Rehman, R.; Baig, M.; Khan, T.A. New roles of the multidimensional adipokine: Chemerin. Peptides 2014, 62, 15-20. [CrossRef] [PubMed]

77. Chakaroun, R.; Raschpichler, M.; Klöting, N.; Oberbach, A.; Flehmig, G.; Kern, M.; Schön, M.R.; Shang, E.; Lohmann, T.; Dreßler, M.; et al. Effects of weight loss and exercise on chemerin serum concentrations and adipose tissue expression in human obesity. Metabolism 2012, 61, 706-714. [CrossRef]

78. Jialal, I.; Devaraj, S.; Kaur, H.; Adams-Huet, B.; Bremer, A.A. Increased chemerin and decreased omentin-1 in both adipose tissue and plasma in nascent metabolic syndrome. J. Clin. Endocrinol. Metab. 2013, 98, E514-E517. [CrossRef]

79. Shan, Y.U.; Zhang, Y.; Li, M.Z.; Hua, X.U.; Qian, W.A.N.G.; Jun, S.O.N.G.; Peng, L.I.N.; Zhang, L.; Qian, L.I.U.; Huang, Q.X.; et al. Chemerin and apelin are positively correlated with inflammation in obese type 2 diabetic patients. Chin. Med. J. 2012, 125, 3440-3444.

80. Adamiak, P.; Łacka, K. Adipose tissue, adipokines and aging. Pol. Merkur. Lekarski 2016, 40, 122.

81. El-Deeb, T.S.; Bakkar, S.M.; Eltoony, L.; Zakhary, M.M.; Kamel, A.A.; Nafee, A.M.; Hetta, H.F. The adipokine chemerin and fetuin-a serum levels in type 2 diabetes mellitus: Relation to obesity and inflammatory markers. Egypt J. Immunol. 2018, 25, 191-202.

82. Klöting, N.; Fasshauer, M.; Dietrich, A.; Kovacs, P.; Schön, M.R.; Kern, M.; Stumvoll, M.; Blüher, M. Insulin-sensitive obesity. Am. J. Physiol. Endocrinol. Metab. 2010, 299, 506-515. [CrossRef] [PubMed]

83. Tönjes, A.; Fasshauer, M.; Kratzsch, J.; Stumvoll, M.; Bluher, M. Adipokine pattern in subjects with impaired fasting glucose and impaired glucose tolerance in comparison to normal glucose tolerance and diabetes. PLoS ONE 2010, 5, e13911. [CrossRef] [PubMed] 
84. Ouwens, D.M.; Bekaert, M.; Lapauw, B.; Van Nieuwenhove, Y.; Lehr, S.; Hartwig, S.; Calders, P.; Kaufman, J.M.; Sell, H.; Eckel, J.; et al. Chemerin as biomarker for insulin sensitivity in males without typical characteristics of metabolic syndrome. Arch. Physiol. Biochem. 2012, 118, 135-138. [CrossRef] [PubMed]

85. Bozaoglu, K.; Bolton, K.; McMillan, J.; Zimmet, P.; Jowett, J.; Collier, G.; Walder, K.; Segal, D. Chemerin is a novel adipokine associated with obesity and metabolic syndrome. Endocrinology 2007, 148, 4687-4694. [CrossRef] [PubMed]

86. Sledzinski, T.; Korczynska, J.; Hallmann, A.; Kaska, L.; Proczko-Markuszewska, M.; Stefaniak, T.; Sledzinski, M.; Swierczynski, J. The increase of serum chemerin concentration is mainly associated with the increase of bodymass index in obese, non-diabetic subjects. J. Endocrinol. Investig. 2013, 36, 428-434.

87. Bobbert, T.; Schwarz, F.; Fischer-Rosinsky, A.; Maurer, L.; Möhlig, M.; Pfeiffer, A.F.H.; Mai, K.; Spranger, J. Chemerin and prediction of Diabetes mellitus type 2. Clin. Endocrinol. 2015, 82, 838-843. [CrossRef]

88. Rabe, K.; Lehrke, M.; Parhofer, K.G.; Broedl, U.C. Adipokines and insulin resistance. Mol. Med. 2008, 14, 741-751. [CrossRef]

89. Fatima, S.; Iqbal, N. Chemerin as a potential screening marker for sub-clinical diabetes? Endocr. Abstr. 2014. [CrossRef]

90. Kim, M.-H.; Chang, Y.; Jung, H.-S.; Shin, H.; Ryu, S. Impact of self-rated health on progression to a metabolically unhealthy phenotype in metabolically healthy obese and non-obese individuals. J. Clin. Med. 2019, 8, 34. [CrossRef]

91. Tsatsoulis, A.; Paschou, S.A. Metabolically healthy obesity: Criteria, epidemiology, controversies, and consequences. Curr. Obes. Rep. 2020, 9, 109-120. [CrossRef]

92. Esteghamati, A.; Ghasemiesfe, M.; Mousavizadeh, M.; Noshad, S.; Nakhjavani, M. Pioglitazone and metformin are equally effective in reduction of chemerin in patients with type 2 diabetes. J. Diabetes Investig. 2014, 5, 327-332. [CrossRef] [PubMed]

93. Fodor, A.; Cozma, A.; Suharoschi, R.; Sitar-Taut, A.; Roman, G. Clinical and genetic predictors of diabetes drug's response. Drug Metab. Rev. 2019, 51, 408-427. [CrossRef] [PubMed]

94. Fülöp, P.; Seres, I.; Lorincz, H.; Harangi, M.; Somodi, S.; Paragh, G. Association of chemerin with oxidative stress, inflammation and classical adipokines in non-diabetic obese patients. J. Cell. Mol. Med. 2014, 18, 1313-1320. [CrossRef] [PubMed] 